\section{Contemporary Indian Philosophy}

By M. K. Gandhi, Rabindranath Tagore, Swāmi Abhedānanda, K. C. Bhattacharyya, G. C. Chatterji, Ananda K. Coomaraswamy, Bhagavan Das, Surendranath Dasgupta, Hiralal Haldar, M. Hiriyanna, S. Radhakrishnan, R. D. Ranade, V. Subrahmanya Iyer, A. R. Wadia. Edited by Dr. S. Radhakrishnan and Prof. J. H. Muirhead. (Library of Philosophy.) Pp. 375. (London: George Allen and Unwin, Ltd., 1936.) 16s. net.

T $T$ is for the mutual benefit of Eastern and 1 Western philosophers that such books as the present are published. A clarification of Indian thought is just as important to Indians themselves as to the growing number of European scholars who make a technical study of Indian thought. Of the fourteen thinkers who contributed to the present volume, Gandhi and Tagore belong to Indian national life, and their messages are incorporated more for their moral influence than for their expert value. But the essays of the other writers provide much food for reflection.

Meditating "On the Pertinence of Philosophy", Dr. Coomaraswamy suggests that the highest wisdom is obtainable by finding what is common to different religions and by constructing a rational metaphysics on these common elements. An example of the method proposed is given in a comparative study of the idea of immortality. Discussing "The Spirit in Man", Sir S. Radhakrishnan reconciles theism and absolutism. But both are rejected by Prof. Wadia, as giving no explanation of evil, in favour of pragmatic idealism. The suggestive study of Prof. Dasgupta on "The Philosophy of Dependent Emergence" and Prof. Hiriyanna's essay on "The Problem of Truth" will be read with much interest, while Prof. Ranade's contribution, in which he proposes to reach truth by a critical interpretation of the great philosophers, is perhaps the most original of the series. An excellent study of Vedantic philosophy is given by Subrahmanya Iyer, who discusses maya (illusion) and the three states of the soul (waking, dreaming and sleeping).

On the whole, the essays contained in this book deal mainly with personal philosophy and religious problems; and they show, with the exception of those of Prof. Dasgupta and Prof. Chatterji, that absolutism is in great favour in contemporary Indian thought. This is an indication of the strong influence of religion on philosophy, which will continue to be an outstanding characteristic of the Hindu mind.

T. G.

The Structure and Development of the Fungi By Dame H. C. I. Gwynne-Vaughan and Dr. B. Barnes. Second edition. Pp. xvi +449. (Cambridge : At the University Press, 1937.) 18s. net.

TEACHERS and students of botany and mycology will warmly welcome the second edition of this well-known book. During the decade which has elapsed since the book was first published, research on the fungi has been ardently pursued; much additional knowledge has therefore been incorporated in the present edition, illustrated by figures of the same excellence as characterized the book originally. Among many new features one is glad to see the inclusion of a section on the interesting group of the Blastocladiales, an account of the recently discovered function of the spermatia of the rusts, and a much fuller discussion of the phenomena of heterothallism and variation in the fungi than was possible in 1927. Some new methods are described in the chapter on technique, and the references to literature have, in general, been brought up to date.

As indicated by the title, the book deals primarily with the morphology of the fungi, and only in a subsidiary manner is their mode of life discussed. In a few instances reference to the latter has not incorporated recent work : for example, some authorities consider that the primary cause of larch canker is frost and not Dasyscypha Willkommii, and fresh light has been thrown on the parasitism of Epichloe typhina and Armillaria mellea. It is now scarcely true to say that the Ustilaginales are obligate parasites, for several species have been cultivated on artificial media. Ustilago Carbo, treated as a single species, is really a complex of species with diverse life-histories. These, however, are but minor imperfections in a book of generally supreme excellence. In fact, the authors have described the structure and development of the fungi so well that an urgent appeal can be made to them either to include a fuller account of the general biology of these organisms in the next edition or to write a companion volume on this theme.

Physik für Stüdierende an Technischen Hochschulen und Universitäten

Von Dr. Paul Wessel. Herausgegeben von Dr. V. Riederer von Paar. Pp. xii + 550. (München : Ernst Reinhardt, 1938.) 4.90 gold marks.

7 HIS text-book of physics for engineers and technical college students is a kind of pocket. edition of an intermediate course in physics with certain elaborations and unusual features. While the fundamentals are surveyed, in an effective and extremely compact manner, in two main divisions of the work extending over some 350 pages in which special reference is made to $\mathrm{X}$-rays and crystal structure and to atomic physics, the whole of the foregoing material is later re-surveyed in a more condensed fashion as a revision course occupying some 50 pages. This is followed by another 50 pages containing a series of questions and answers, the latter usually taking the form of a reference to the appropriate page on which the relevant information necessary for a correct answer is to be found. Finally are given a goodly collection of mathematical and physical tables, where, in addition to much useful data normally required by engineers and physicists and to be expected in a book of this nature, are given tables such as those of the isotopes of xenon, the families of radioactive elements and the wavelengths of the $K$ series of the X-ray spectra of various elements, the usefulness of which is not obvious.

The work is well illustrated and indexed, and should be most helpful to English-speaking students who wish to acquire a knowledge of scientific German.

L. F. B. 